\title{
Robust cropping systems to tackle pests under climate change. A review
}

\author{
Jay Ram Lamichhane • Marco Barzman • Kees Booij • Piet Boonekamp • Nicolas Desneux • \\ Laurent Huber • Per Kudsk • Stephen R. H. Langrell • Alain Ratnadass • Pierre Ricci • \\ Jean-Louis Sarah • Antoine Messéan
}

Accepted: 21 November 2014 / Published online: 30 December 2014

(C) The Author(s) 2014. This article is published with open access at Springerlink.com

\begin{abstract}
Agriculture in the twenty-first century faces the challenge of meeting food demands while satisfying sustainability goals. The challenge is further complicated by climate change which affects the distribution of crop pests (intended as insects, plants, and pathogenic agents injurious to crops) and the severity of their outbreaks. Increasing concerns over health and the environment as well as new legislation on pesticide use, particularly in the European Union, urge us to find sustainable alternatives to pesticide-based pest management. Here, we review the effect of climate change on crop protection and propose strategies to reduce the impact of future invasive as well as rapidly evolving resident populations. The major points are the following: (1) the main consequence of climate change and globalization is a heightened level of unpredictability of spatial and temporal interactions
\end{abstract}

The views expressed by Stephen R. H. Langrell are purely his own and may not in any circumstances be regarded as stating an official position of the European Commission.

J. R. Lamichhane $(\varangle) \cdot$ M. Barzman · A. Messéan

INRA, UAR1240 Eco-Innov, BP 01, 78850 Thiverval-Grignon,

France

e-mail: jayram.lamichhane@gmail.com

J. R. Lamichhane

e-mail: Jay-Ram.Lamichhane@grignon.inra.fr

K. Booij · P. Boonekamp

Plant Research International (PRI), Wageningen University, Postbus

69, 6700AB Wageningen, The Netherlands

N. Desneux $\cdot$ P. Ricci

INRA, UMR1355-ISA, BP 167, 06903 Sophia Antipolis, France

L. Huber

INRA, UMR1091 EGC, 78850 Thiverval-Grignon, France

P. Kudsk

Department of Agroecology, Aarhus University, Forsoegsvej 1, 4200 Slagelse, Denmark between weather, cropping systems, and pests; (2) the unpredictable adaptation of pests to a changing environment primarily creates uncertainty and projected changes do not automatically translate into doom and gloom scenarios; (3) faced with uncertainty, policy, research, and extension should prepare for worst-case scenarios following a "no regrets" approach that promotes resilience vis-à-vis pests which, at the biophysical level, entails uncovering what currently makes cropping systems resilient, while at the organizational level, the capacity to adapt needs to be recognized and strengthened; (4) more collective approaches involving extension and other stakeholders will help meet the challenge of developing more robust cropping systems; (5) farmers can take advantage of Web 2.0 and other new technologies to make the exchange of updated information quicker and easier; (6) cooperation

\section{S. R. H. Langrell}

Agriculture and Life Sciences in the Economy Unit Institute for Prospective Technological Studies (IPTS) European Commission-Joint Research Centre (JRC) Edificio EXPO, 41092 Seville, Spain

A. Ratnadass

Agricultural Research Centre for International Development (CIRAD) HortSys Research Unit, TA B-103/PS4F-3439, Montpellier Cedex 5, France

J.-L. Sarah

Agricultural Research Centre for International Development (CIRAD), TA 179/04 Avenue Agropolis, 34398 Montpellier Cedex 5, France

Present Address:

S. R. H. Langrell

European Commission, DG Health and Consumer Protection, Food and Veterinary Office, Grange, Co. Meath, Ireland 
between historically compartmentalized experts in plant health and crop protection could help develop anticipation strategies; and (7) the current decline in skilled crop protection specialists in Europe should be reversed, and shortcomings in local human and financial resources can be overcome by pooling resources across borders.

Keywords Climate change $\cdot$ European network $\cdot$ Integrated pest management $\cdot$ Pest evolution $\cdot$ Research priority ·

Sustainable agriculture

\section{Contents}

1. Introduction.

2. Policy and regulatory issues related to climate change scenarios

3.Pest evolution under climate change..

3.1. Insects

3.2. Fungi

3.3. Bacteria

3.4. Weeds

4. Diversification of current plant protection strategies to mitigate climate change effects.

5. Priorities and action points to improve current plant protection practices.

5.1. Human resources

5.2. Resilient cropping systems.

5.3. Crop weed competition.

5.4. Anticipation and international monitoring

5.5. Breeding for resistance.

5.6. Biological control.

5.7. Pest risk analysis.

6. Conclusion

7. Acknowledgements.

8. References

\section{Introduction}

The earth's climate is changing in response to several human activities which markedly contribute to global climate changes (Pachauri and Reisinger 2007). Agriculture, forestry, and other land uses are responsible for approximately $25 \%$ of anthropogenic greenhouse gas (GHG) emissions mainly from deforestation and agricultural emissions (Bustamante et al. 2014; IPCC 2014). Over the last century, there have been consistent increases in $\mathrm{CO}_{2}$ emissions which led to an increase in global mean temperature of $0.74{ }^{\circ} \mathrm{C}$, and this is projected to continue at a pace between 0.15 and $0.3{ }^{\circ} \mathrm{C}$ per decade, based on the emission scenario (IPCC 2007; Watson 2001). By the end of the twenty-first century, temperature is projected to rise by $3.4{ }^{\circ} \mathrm{C}$ while atmospheric $\mathrm{CO}_{2}$ concentration will be almost four times higher than that of today (Pachauri and Reisinger
2007; IPCC 2014). Such a scenario raises questions on the sustainability of current cropping systems which are likely to be impacted under climate change. Concomitantly, global food production must increase by $50 \%$ to meet the projected demand of the world's population by 2050 (Chakraborty and Newton 2011; Foley et al. 2011). This difficult challenge is further complicated by climate change which influences the distribution of crop pests (i.e., insects, pathogens, and weeds) and disease severity. Although pest management has played an important role in the marked rise in food production in the last 50 years (Oerke 2006), most existing management strategies have been based on the indiscriminate use of pesticides in agriculture. Increasing awareness of health and environmental issues as well as increasingly stringent legislation on pesticide use, particularly in the European Union (EU), pose a particular compounded challenge to twenty-first century agriculture. EU agriculture needs to meet food demands, satisfy sustainability goals, and adapt to climate change. Indeed, maintaining, or even increasing, crop yield while simultaneously reducing reliance on pesticides represents a challenging task (Hossard et al. 2014) that is further complicated against the background of climate change scenarios.

In the current situation, two factors increase the risk of potential pest pressure in agriculture. While increasing anthropogenic impact, in particular increasing global movement of people and trade of plant commodities, continues to lead to the introduction of exotic pests into new regions (Fig. 1), climate change provides suitable conditions for such pests to adapt across the areas which were previously detrimental for their survival (Chakraborty 2013; Fletcher et al. 2010). In this way, climate change further accelerates pest pressure both in space and time and may have dramatic consequences throughout specific regions of the globe. In some regions, excessively dry, wet, or warm conditions may directly hamper crop production and consequently current crop protection methods may become ineffective (Chakraborty and Newton 2011). Recent examples of pest adaptation to warmer temperatures (see below) have given rise to escalating disease epidemics in new areas where, in retrospect, the current cropping systems are excessively vulnerable to unforeseen threats. Even less direct effects, such as changes in crop or pest phenology can also have significant consequences in plant production.

Crop losses due to pests can account of up to more than $40 \%$ worldwide (Oerke 2006). These values might significantly rise under changing climatic conditions whereby new and more aggressive pests affect levels and stability of crop yield thereby threatening food security. However, it is not possible to make estimates on overall potential crop losses due to climate change. This is in part because of the unpredictable adaptation of certain pests to a changing environment which creates situations of uncertainty (Chakraborty and Newton 2011). Indeed, the main consequence of climate change and accelerated globalization is a heightened level of 
Fig. 1 South American tomato moth (Tuta absoluta) and the damage it causes on tomato. This pest arrived in Europe (Spain) in 2006 and rapidly spread in AfroEurasia (Desneux et al. 2011). It is currently widespread throughout most European countries
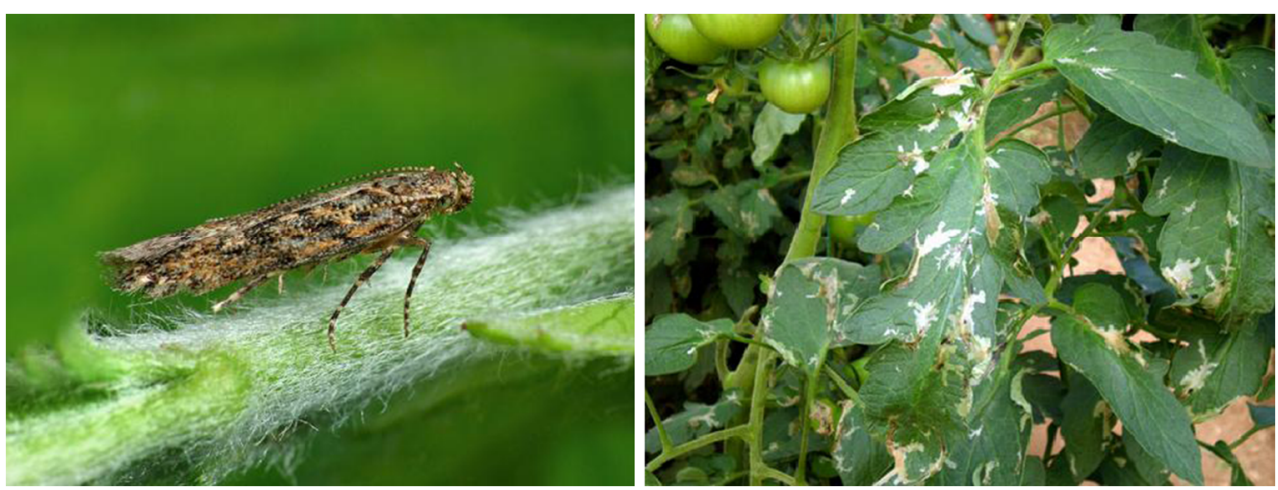

unpredictability regarding spatial and temporal interactions between weather, cropping systems, and pests (Chakraborty 2013). This is the ongoing crop protection challenge that farmers, advisers, researchers, and policy makers face.

In light of this, the reduction of pest impact has become more relevant than ever not only to produce sufficient food and agricultural commodities but also to reduce excessive input and unnecessary $\mathrm{CO}_{2}$ emissions. Interactions between the changing environment, crops, cropping systems, and pests demand a new multi-disciplinary and integrative knowledge base for the development of viable adaptive strategies. The capacity to adapt is needed to reduce the impact of both invasive alien species as well as rapidly evolving resident pest populations (Chakraborty 2013; Roy et al. 2014). Here, we contend that anticipatory strategies, enhanced adaptation capacity, and the development of more resilient cropping systems require new insights and innovative organizational change. Because this paper is the fruit of collaborations among several European partners, we will mainly focus on scenarios of climate change and pest evolution within European contexts. Our objective is to identify relevant research needs and policy implications in order to understand how cropping systems and integrated pest management (IPM) strategies can be designed to better deal with invasive as well as existing but evolving pest populations under climate change in Europe. In particular, we use two major approaches. For emerging invasive alien pests that, should they evade biosecurity measures, are likely to become established, we seek approaches to reduce their impact, while for indigenous pests, we seek prevention, escape, or control strategies to manage plant-pest evolutionary processes.

\section{Policy and regulatory issues related to climate change scenarios}

Climate change is increasingly recognized as a considerable risk to agriculture in the European Union, in particular with respect to direct impacts on crop production and the stability of yields. It is becoming increasingly central within the
European policy agenda, mainly with respect to EU food security. Potential adaptation of existing pest populations to new environments, as well as exotic incursions of new, betteradapted pest genotypes or species, will further add to the lack of predictability and stability of current cropping systems. However, indirect losses in cropping systems due to climate change, through the probable changing impact of pest and diseases, have received very little attention or recognition compared to human or animal health issues.

In order to reduce crop losses due to either invasive or rapidly evolving resident pests under changing climate, the further integration of the roles of plant health and crop protection specialists for the creation of more resilient cropping systems appears increasingly relevant. Such recognition, although still rather tentative and subject to further policy integration and elaboration, is consistent within the framework of adaptive strategy needs as outlined in the European Commission White Paper, adapting to climate change: towards a European framework for action (COM(2009) 147/4) (European Commission 2009a). Nevertheless, specific actions remain to be outlined.

The impact of climate change, globalization, and increased intra-community movement on the introduction and spread of invasive alien and existing pests, respectively, is considered as one of the central concerns of the current revision of the Common Plant Health Regime (http://ec.europa.eu/food/ plant/strategy/index_en.htm). In particular, there is an emphasis on the sustainability with regard to the potential increased pressures on cropping systems and yields and overall food security. Recent and potentially future legislation responding to increasingly stringent environmental and human health concerns-for example, Regulation (EC) No. 1107/2009 (European Commission 2009b) and Directive 2009/128/EC (commonly referred to as the Framework Directive) (European Commission 2009c) and their respective implications - while fuelling innovation toward environmental and health sustainability may add further practical and operational challenges with regard to maintaining the same level of crop yields. It is unclear, however, how both pest evolution and legislative scenarios will be 
changed in the coming future given the uncertainty on their medium- and longer-term individual and interactive impacts. Of equal concern is also their possible impact on cropping system resilience and the capacity to adapt.

\section{Pest evolution under climate change}

Plausible estimates of climate change impacts require combined use of climate, crops, pests, and economic models. However, climate change models often ignore possible effects on dynamics and infectivity of pests and diseases. The most important reason is that we do not have long-term monitoring data or an empirical approach to feed modeling systems that might be used to predict impacts and mitigation scenarios with sufficient levels of certainty (Scherm 2004; Shaw and Osborne 2011). In addition, this pattern of climate change factors is not equally distributed over the globe. It is anticipated that a general shift of a milder climate toward the poles will improve the potential of crop production (Butterworth et al. 2010; Evans et al. 2008). By contrast, hotter and drier conditions in many already semi-arid areas of the world will limit the possibilities for agriculture (Luo et al. 2009). Therefore, it is unlikely that general models can ever be developed. However, it is worth noting that all climate models predict a higher frequency of extreme and fluctuating weather conditions which would influence the interactions between crops, pests, and diseases in an unpredictable way. As a consequence, there may be increasing risk of complete failure of current and possibly future crop protection strategies.

Climate change is generally associated with increased $\mathrm{CO}_{2}$ levels, higher seasonal temperature profiles, and more precipitation (Pachauri and Reisinger 2007). These global climate change effects will affect the distribution of pests, although whether such changes will cause more frequent and more severe outbreaks cannot be answered in general terms. The fertilization effect of higher $\mathrm{CO}_{2}$ levels might increase photosynthesis and crop yields (Ainsworth and Long 2005). However, it is widely considered to also affect plant morphology, canopy structure, and hence micro-climate and the resident micro-floral populations in such environments (Eastburn et al. 2011). Thus far, different studies have given conflicting results showing that elevated $\mathrm{CO}_{2}$ levels may have negative, neutral, or positive effects on fungal growth (Luck et al. 2011). Indeed, the Climapest project, covering 20 different crops throughout Brazil, concluded that climate change can "decrease, increase, or have no impact on plant diseases, pests, or weeds depending on the region and the time period" (http://www. macroprograma1.cnptia.embrapa.br/climapest/englishversion). For example, experiments showed that in an environment with higher $\mathrm{CO}_{2}$ level, some rust-caused diseases seemed to increase while others decreased in severity (Ghini et al. 2011).
The effects of temperature change are manifold and will affect crops and plant diseases in many different direct and indirect ways. For example, a $5.8^{\circ} \mathrm{C}$ increase in temperature is expected to reduce suitable coffee-growing areas by more than $95 \%$ in several regions of Brazil (Assad et al. 2004). Higher temperatures are often associated with increased rates of development, growth, and reproduction and hence the fear that plant diseases will become more severe makes intuitive sense. Warmer climate crops, such as those found in the tropics, tend to suffer greater pest problems than crops in more temperate regions. Yet, it is not easy to predict which combinations of crops and pests will tend to become problematic in the future and in which areas (Shaw and Osborne 2011). On the other hand, higher levels of precipitation in certain areas could be useful for plant growth, although rainfall and moisture are also vital for the occurrence of fungal and bacterial species (Huber and Gillespie 1992). Infection, sporulation, and spread of many fungi are moisture-dependent, and outbreaks are often triggered by long periods of wetness (Juroszek and von Tiedemann 2011).

The body of knowledge on the effects of climate change, new exotic pest incursions, and globalization on crop protection points to a higher level of unpredictability regarding future crop-pest-climate interactions and increased frequency and amplitude of climatic fluctuations. Overall, there will be accelerations in the rate of exotic pests entering and establishing in Europe as well as an increased rate of evolution of existing pest populations. In such situations, the priority may shift from maximizing yields to achieving more stable levels of production and avoiding total crop failures. Hence, IPM strategies that are dynamic and internally diversified to locally adapted cropping systems, and more resilient to fluctuating weather conditions and new and evolving pests, should be developed accordingly.

A wide range of pests including insects, fungal and bacterial pathogens, and weeds may benefit from changing climate. The way in which climate change impacts their evolution can be summarized as below.

\subsection{Insects}

Climate and weather patterns are of primary importance for the distribution, development, and population dynamics of insects. Although insects may regulate body temperature within a certain range, many species - especially smaller herbivores-are almost exclusively ectotherms (Willmer et al. 2000). Insect physiology is therefore primarily driven by temperature which means that phenology, reproduction, and developmental rates significantly change when populations are exposed to different climatic regimes. Bioclimatic envelopes (the range and pattern of climatic parameters) and day length largely determine the potential distribution of insect species when host plants are available. 
Insects are constantly adapting their life history patterns to the available climatic regimes or season lengths. Evolutionary adaptations in life cycles of insects occur so rapidly that ongoing climate changes are already reflected in according adaptations such as daylight signals that induce diapause (Bradshaw and Holzapfel 2011). Increased pest outbreaks were judged as "virtually certain" in the previous IPCC Synthesis Report (IPCC 2007), while according to the IPCC Synthesis Report 2014, increases in the frequency or intensity of ecosystem disturbances including pest outbreaks in many parts of the world are in some cases due to climate change (IPCC 2014). Aside from population dynamics per se, current climatic projections predict that the distribution of insect species will shift from lower latitudes pole wards and from lower to higher altitudes (Hadley Centre 2007). Such range shifts in insect distributions have been already observed in nature as a response to global warming (Battisti et al. 2005; Gutierrez et al. 2009; Parmesan 2006; Walther et al. 2002). For example, the stinkbug Acrosternum hilare in England and Japan has shifted its range by more than $300 \mathrm{~km}$ northward with a temperature increase of only $2{ }^{\circ} \mathrm{C}$ (Trumble and Butler 2009). Likewise, the mountain pine beetle, a major forest pest in the USA and Canada, has extended its range northward by approximately $300 \mathrm{~km}$ when temperature rose by only $2{ }^{\circ} \mathrm{C}$ (Logan and Powell 2001).

Lower latitudes usually have more complex pest assemblages, i.e., more pest species and antagonists per crop than higher latitudes toward the poles. Climatic shifts are therefore expected to increase the number of harmful species in temperate regions, especially in those of the northern hemisphere (Logan and Powell 2001; Parmesan 2006). For example, higher temperatures may extend the distribution range of the European corn borer (Ostrinia nubilalis) to maize areas previously free of this species. This may not only lead to crop losses but also to more secondary infections by Fusarium molds and consequent mycotoxin problems in this crop. Pests may also spread or invade into areas and find new host plants that were not infested before. Being the driving factor for establishment in new distribution ranges, global warming may also increase the traveling speed of invasive pests by decreasing the function of mountain ranges as cold barriers (Aluja et al. 2011).

Climate change will lead also to phenological changes. The earlier onset and increased length of the growing season also means that indigenous polyvoltine species may be able to complete more generations per year leading to higher population levels at the season's end (Ziter et al. 2012). In this way, formerly univoltine species may also become bi- or multivoltine as reported for codling moth (Cydia pomonella L.), a key pest in apple throughout several parts of Europe (Stoeckli et al. 2012). Shifts in phenology due to changing temperatures may also change the synchrony between host plants, pest species, and their natural enemies. This may lead to unexpected interactions the outcome of which, in terms of more or less damage, is hard to predict. Furthermore, invasive species may have more opportunity to become established in areas that were formerly unsuitable as a habitat due to the climatic conditions (Trumble and Butler 2009).

Besides higher population pressure, the potential for damage is expected to last longer within the growing season and crops will have to be protected accordingly. Established management strategies that are focused on low pesticide residues will have to be largely adapted to avoid the possible resistance build-up to plant protection chemicals thereby ensuring their sustainability in future use (Samietz et al. 2014). Here, further knowledge about pest biology, especially the potential adaptation of insect pests to climatic changes, is necessary and needs to be combined in simulation studies in order to prepare management systems that can withstand the challenges of global warming.

Besides higher temperatures during the growing season, elevated winter temperatures are equally significant. The distribution of many species is limited by their low-temperature tolerance. Given milder winters under climate change, more species will be able to survive and colonize crops. Some species may skip their sexual stage and have new asexual generations throughout the year which may lead to early high population levels. There are a number of instances worldwide where aphids have shifted from holocyclic (primary and secondary hosts) to anholocyclic (only secondary hosts, i.e., only the crop plants) form (Radcliffe and Ragsdale 2002). Such a shifting process in insect phenology is likely to have an impact on crops and increase pest management costs. An example of altered aphid phenology comes from Scotland whereby oilseed rape production was introduced with farmers growing vernalized oil seed rape (autumn planted with the crop remaining green during the winter). It was found that green peach aphids could overwinter as anholocyclic forms (asexual generations) on oilseed rape and colonize potato earlier than those aphids that overwintered on the primary host (Fenton et al. 1998; Woodford 1998). If increased temperatures allow aphids to remain on secondary hosts (either crop or non-crop), this can result in rapid colonization of crops early in the season. The phenology of pests will also be modified by increased temperatures. A 20-year study in the UK demonstrated that winter temperature was the dominant factor affecting aphid phenology and that a mere $1{ }^{\circ} \mathrm{C}$ rise in winter temperature advanced the migration phenology by 19 days (Zhou et al. 1995). Overall, higher temperatures would allow insect populations to colonize crops earlier and develop faster. In this way, crop damage may occur more rapidly than what is currently observed. Finally, as some of these insect species are also vectors of viruses (such as Bemisia tabaci), crops may also become more vulnerable due to earlier and more severe infections. 
Besides temperature, elevated $\mathrm{CO}_{2}$ levels were reported to favor insect population growth rates, such as those for pea aphids, by active elicitations of host responses that promote amino acid metabolism in both the host plant and its bacteriocytes (Guo et al. 2013). In addition, rising $\mathrm{CO}_{2}$ levels will increase the carbon-nitrogen balance in crop plants and hence their structure and palatability for leaf chewing insects. Each species may respond differently to all these changes, and this will affect concentrations of constitutive and induced defensive chemicals in plants, insect feeding behavior, competition between pests, interactions among pests and natural enemies, and ultimately damage to crops (Trumble and Butler 2009). However, our current knowledge on these aspects remains largely fragmentary.

Over recent decades, there has been constant growth in the number of reports of invasive alien species reaching new areas (Trumble and Butler 2009). Invasions are primarily due to increasing anthropogenic impacts at global level, i.e., the increasing and rapid movement of people and agricultural commodities. However, warmer temperatures also mean that insects which could not previously survive in potential new areas are able to establish and colonize once introduced. A practical example is the potato psyllid (Bactericera cockerelli) which has migrated to California several times over the past century with the populations never lasting more than a year. Cool winter temperatures meant it could only survive in Mexico and southern Texas during this period of the year. However, in 2000, it became established in California inducing substantial losses in tomato, potato, and pepper crops (Liu and Trumble 2007).

New emerging species often spread into completely new ecological settings where most of their natural enemies are missing. An example is the introduction of the B-biotype (B. tabaci) in Brazil which was responsible of vectoring of viruses present in native plants only onto cultured tomato crops, leading to new virus diseases in this crop (Fernandes et al. 2008). Whether antagonists will also extend their ranges, thereby following the herbivores, is unknown for the moment. This is true especially in the case of introduction via globalization/international trade rather than the mere extension of an area of distribution via climate change. In-depth ecological knowledge about both pests and their natural enemies in the country of origin may help toward better preparedness and to develop more robust cropping systems. This may apply to both already introduced pests and vectored diseases such as Tuta absoluta (Desneux et al. 2010; Zappalà et al. 2013), B. tabaci (Tahiri et al. 2006), tomato yellow leaf curl virus (TYLCV), Plutella xylostella, and its parasitoids (Sarfraz et al. 2005), and to potential invasive species such as Bactrocera fruit flies (Stephens et al. 2007). Robust cropping systems were already developed and tested in the tropics against a range of such pests (Licciardi et al. 2008; Vayssieres et al. 2009).

\subsection{Fungi}

Plant disease outbreaks depend on complex interactions between many factors. Overall, the development of an aggressive strain within a diverse population, the presence of host plants missing appropriate resistance to this newly developed aggressive strain, plant architecture, uniform cropping system, weather conditions, and limited antagonistic activities of nonpathogenic populations play an important and inter-related role (Barbetti et al. 2012; Burdon et al. 2006; Garrett et al. 2011; Jones and Barbetti 2012; Pangga et al. 2013). The mode of nutrition also has a non-negligible role. For example, biotrophic fungi deriving nutrition only from living host tissue are more successfully controlled than necrotrophs which derive nutrition from both live and dead plant materials (Beed et al. 2011). Taking all these factors together, it is hard to speculate on the effects of climate change, particularly when long-term datasets from the past are missing to develop and test predictive models for the future. Nevertheless, our knowledge of the phenology of plant-disease interactions, population genetics of pathogens as well as crops, and examples of overwhelming establishment of new diseases in a region provides insights into how climate change may affect disease incidence and severity as summarized below.

Firstly, some features of climate change will influence disease phenology. Higher temperatures and/or elevated $\mathrm{CO}_{2}$ will speed up the life cycle of some pathogenic fungi thereby increasing the development and availability of inoculum. The latter of which may lead to high levels of infection and accelerated evolution of new aggressive strains (Chakraborty and Dutta 2003). Hence, crop protection practices must be timely, effective, precise, and complete to prevent a new wave of infection that leads to new disease epidemics due to overcoming crop resistance. Prolonged generations of pests will be able to infect crops at a later stage than at present. An example is Phoma which is estimated to cause a $10-50 \%$ decrease in the total yield of oilseed rape in the UK depending on future climate conditions (Barnes et al. 2010). Climate change was also reported to alter crop anthesis. For example, wheat in the UK will be developed earlier in the season being more favorable for Fusarium ear blight infection and consequent mycotoxins increases in cereal products (Madgwick et al. 2011).

Secondly, climate change may affect the expression of plant resistance traits in a positive or negative way. Breeding for resistance is a lengthy process, and today's resistant varieties are specifically bred for present agricultural conditions. The expression of quantitative resistance against Phoma in oilseed rape dropped dramatically when there was an increase in temperature from 20 to $25^{\circ} \mathrm{C}$ (Huang et al. 2009). Indeed, the authors showed that the percentage of leaf area infected increased from 5 to $50 \%$. Taken together, the expression of resistance genes in the host plant, and their efficacy, may decrease dramatically because of climate change. In addition, 
we could envisage that increased generation cycles of pests triggered by climate change might select more aggressive pathogen populations (Chakraborty 2013). Such a selected population, combined with hampered resistance in the host, may lead to unpredicted, or unprecedented, epidemiological outbreaks.

Thirdly, when the genetic variation of a crop is low, particularly over a wide range, and continued series of cultivation, a new or adapted strain of a pathogen may arise and become dominant thereby leading to dramatic effects (Strange and Scott 2005). A classic example is wheat production in the Central, West Asian, and North African regions which feeds more than one billion people. Although many wheat varieties are grown in this huge area, all have a similar genetic background. With a slightly increased temperature and decreased rainfall, as observed over recent decades, a new type of yellow rust caused by Puccinia striiformis (Hovmøller et al. 2011) was able to extend from Africa to India within 15 years. This has led to widespread epidemics highlighting how vulnerable an area can be when slight changes in climate occur (Wellings 2011). Indeed, it was reported that new strains of the fungus have adapted to produce spores at warmer temperatures than usual for this pathogen. This may have probably increased the rate of disease expansion on a global scale (Milus et al. 2009). The new strain of $P$. striiformis (Fig. 2) spreads to at least three new continents within 3 years, faster than previously reported for any crop pathogen (Hovmøller et al. 2008). This gave rise to severe epidemics in warmer wheat production areas (Hovmøller et al. 2010) where yellow rust was previously absent or infrequent, implying that current cropping systems were not prepared for the new situation. At a temperature regime typical for these areas, isolates of the new strain produced three to four times more spores per day than strains found previously (Hovmøller et al. 2011). The rapid spread of the new strain is probably the cumulative result of increased pathogen fitness, warmer environments, increase in the number of spores in the atmosphere, and long-distance dispersal of these by wind, increasing travel and commerce. Similar chains of events should be expected for other pathogens reinforcing the need for coordinated international surveillance (including long-range surveillance) and action to ensure sustainable crop disease management under climate change.

Another example of increasing pathogen proliferation and disease outbreaks is the case of oomycete Phytopthora spp. Root rot and canker disease caused by Phytophthora cinnamomi affects more than 1000 host species, especially in most temperate and subtropical areas of the globe (Sturrock et al. 2011). Under climate change, this pathogen was reported to increase the instability and vulnerability of forest ecosystems by a shift toward central Europe (Jung 2009). Increasing temperatures were predicted to boost potential range expansion of $P$. cinnamomi along the western coast of Europe up to a few hundred kilometers eastward from the Atlantic coast

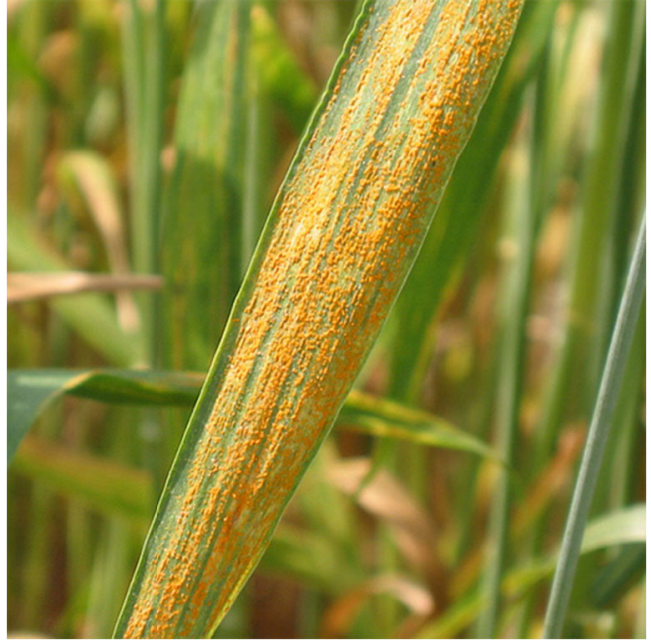

Fig. 2 Yellow rust (Puccinia striiformis) on winter wheat. New strains of this fungus have adapted to produce spores at warmer temperatures than usual

within one century (Bergot et al. 2004). Likewise, Phytophthora ramorum, a pathogen of yet unknown origin, and not reported in Europe until the late 1990s, has rapidly established itself as a major threat to a range of plant species here. Within the last 15 years, over 20 different species of broad-leaved trees were found to be infected throughout southern England (Webber 2008). Since autumn 2009, several dramatic outbreaks of the disease caused by this pathogen have been reported across the UK on several new host species (Brasier et al. 2010; Webber et al. 2010). Thanks to the introduction of new horticultural plant species in Europe (such as rhododendron), and altered weather conditions with humid summers and milder winters, this pathogen was not only able to cross the ocean (which it probably had done previously) but was also able to finally establish itself throughout most European regions. Today, this fungal pathogen is widely considered as endemic in Europe, infecting an increasing range of other host plants. Climate change scenarios based on CLIMEX model (that describes the response of a species to climate) projected that the area favorable, or very favorable, for P. ramorum will markedly decrease in the eastern USA but will increase in the west-coast states of Washington, Oregon, and California (Venette 2009; Venette and Cohen 2006). Numerous other examples of shift in fungal pathogens and disease outbreaks associated to changing climate were recently reviewed (Sturrock et al. 2011).

Besides changes in host-pathogen interactions, climate change leads to other changes including fecundity, canopy size, and long- and short-distance disseminations (Chakraborty 2013). Changes in the geographical distribution of hosts and pathogens, new pathogens, new remnant vegetation, and increased plant stress will all be important issues in the development of fungal diseases in changing climatic conditions. The complex interplay of changing resistance 
expression, new virulence of pathogens, and presence of other host plants and, overarching all these, more favorable infection conditions due to climate change warrant a careful inventory of the new knowledge needed to prevent unprecedented disease outbreaks in the future.

Several examples of fungal pathogen adaptation under climate change have been reported in the literature. Those include the substitution of species in the genus Fusarium and Microdochium spp. in Europe by Fusarium pseudograminearum with higher temperature optima and toxigenicity (Isebaert et al. 2009). This replacement has led to the increased risk of mycotoxin contamination (Paterson and Lima 2010). Similar example was reported also from Canada where adaptive evolution along environmental gradients has replaced existing Fusarium graminearum population with highly toxigenic forms (Ward et al. 2008). In eastern USA, an aggressive high-temperature-tolerant strain has dominated stripe rust pathogen, $P$. striiformis $\mathrm{f}$. sp. tritici, population since 2000 (Milus et al. 2009).

As effects of climate change on fungal diseases are challenging to predict in general terms, a practical method might be detailed through modeling of each individual croppathogen situation in a projected climate change condition of a certain geographic area. Looking at north-west Europe with predicted warmer and more humid winters, and warmer and drier summers, polycyclic and monocyclic fungi can be classified in seven "ecotypes" (West et al. 2012). This classification can be based on parameters such as dissemination method of spores, infection condition requirements, and latent period to weather conditions (West et al. 2012). Being classified in a specific ecotype, one can predict if climate change in that region will support an increased or a decreased infection of a certain fungus-crop combination. This methodology might be useful to test in other regions of Europe.

\subsection{Bacteria}

In a globalized world and under climate change conditions, plant pathogenic bacteria are expected to become an increasing threat to crop health (Jones and Barbetti 2012). Firstly, apparently healthy but latently infected woody plants (Lamichhane 2014; Lamichhane et al. 2014) highly favor the long-distance dissemination of plant pathogenic bacteria through global trade of nursery materials. This often leads to new disease outbreaks throughout the range of cultivation. Secondly, new strains emerge from warmer regions and easily adapt to our more temperate regions. A telling example in Europe can be found in potato crops where diseases caused by Pectobacterium spp. were always predominant. However, over the past decade Dickeya spp. have taken over (Czajkowski et al. 2011). The latter, previously identified as pathogens from tropical and subtropical regions, have become established in Europe due to today's milder climatic

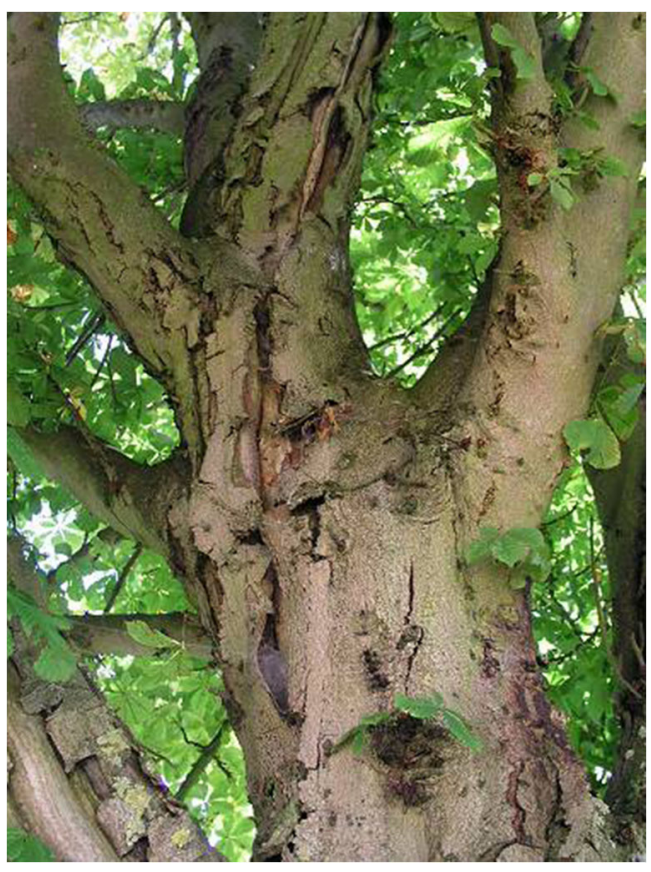

Fig. 3 Horse chestnut bleeding canker caused by the bacterial pathogen Pseudomonas syringae which leads to rapid tree death

conditions. Dickeya spp. are more aggressive than Pectobacterium spp. and are now responsible for 50 to $100 \%$ of field infections thereby leading to significant damage in potato and other crops across Europe (Czajkowski et al. 2011).

European horse chestnut bleeding canker caused by Pseudomonas syringe represents another pertinent example (Fig. 3). Although this pathogen was reported to cause mild disease symptoms on a local horse chestnut species from India during the 1980s (Durgapal and Singh 1980), the pathogen was never reported in Europe. However, in 2002, an aggressive population of $P$. syringae was found on European horse chestnut in the Netherlands which, since, has rapidly established itself as a major threat to this tree throughout a large number of North-western European countries (reviewed by Lamichhane et al. 2014). Similarly, an aggressive population of $P$. syringae has jeopardized the entire kiwifruit industry at global level causing severe economic losses (Bartoli et al 2014; Lamichhane et al. 2014). In this last case, global trade of infected plant materials and the cultivation of genetically uniform plant species were considered as the major means that favored pathogen dissemination.

Another example of bacterial pathogen evolution under climate change includes race 9 of Xanthomonas oryzae pv. oryzae infecting rice with the Xa7 resistance gene increased virulence and aggressiveness over 11 years of rising temperature to dominate the pathogen population (Webb et al. 2011). However, in this case, the increased effectiveness of $\mathrm{Xa} 7$ at high temperature has continued to offer effective pathogen control. 
As climate change might enhance threats from plant pathogenic bacteria, it is important to realize that bacteria might behave as "kingdom hoppers" moving from human to animal to plant to environment and vice versa. These phenomena have raised several concerns. Recent evidence has confirmed that human pathogenic Gram-negative bacteria and viruses can colonize and infect plants as alternate hosts (Holden et al. 2009). The causal agent of nosocomial infections in humans, Pseudomonas aeruginosa (Mesaros et al. 2007), is reported to cause new diseases on naturally grown tobacco (Yu et al. 2008) and causes fruit rot of Tinda (Mondal et al. 2012). Similarly, Salmonella enteric typhimurium internally colonizes tomato ( $\mathrm{Gu}$ et al. 2013; 2011) as well as lettuce (Klerks et al. 2007) plants. On tomato, S. enterica has been reported to move systemically reaching fruits and seeds from leaves ( $\mathrm{Gu}$ et al. 2011). Once within the fruits, the pathogen can multiply to high densities ( $\mathrm{Gu}$ et al. 2011; Noel et al. 2010). A recent study demonstrated that Escherichia coli can internally colonize both leaves and roots of lettuce and spinach (Wright et al. 2013). Lastly, human norovirus and norovirus surrogates (Murine norovirus and Tulane virus) are also reported to colonize spinach stem and leaves (Hirneisen and Kniel 2013). Because virulence effector genes can be frequently exchanged or transferred between bacteria (Baltrus 2013), such "kingdom hopping” events represent a real threat thereby raising several concerns also for human and animal, not least plant health. Recently, it had been reviewed that bacterial species, especially those belonging to the large family of Enterobacteriaceae, can easily be adapted in human, animal, and plant environments. Horizontal gene transfer (Baltrus 2013) between species can easily occur in a joint habitat such as the soil/manure/plant-rhizosphere interphase, which might confer an enhanced fitness to bacteria to live on plant as well as human hosts. In analogy to zoonosis (bacteria transmitted from animal to human), this new class of plant bacteria is termed "phytonosis" (Van Overbeek et al. 2014). One of the most important threats of phytonosic bacteria are acquired genes for antibiotic resistance (Lipsitch et al. 2002), known for being abundantly present in the bacterial community of the plant rhizosphere.

\subsection{Weeds}

Overall, invasive plants have been shown to severely affect plant communities. A recent meta-analysis estimated that invasive plants reduced fitness of native plant communities on average by $41.7 \%$, growth by $22.1 \%$, species abundance by $43.5 \%$, and diversity by $50.7 \%$ (Vilà et al. 2011). More specifically to crops, weeds compete with them for light, nutrients, and water. It is likely that the effect of environmental disturbances such as rising $\mathrm{CO}_{2}$ or increasing temperatures will be manifested as a change in the competitiveness between crops and weeds. Herbicide performance is also expected to reduce at elevated $\mathrm{CO}_{2}$ levels (Ziska 2010). Being inherently adapted to the prevailing conditions, it is likely that weeds will respond more favorably to climate change than crops. This has been confirmed in the majority of studies examining the response of crops and weeds to increasing levels of $\mathrm{CO}_{2}$. However, the physiological characteristics of crops and weeds being either a $\mathrm{C}_{3}$ or $\mathrm{C}_{4}$ plant will also determine their respective responses to $\mathrm{CO}_{2}$ (Hatfield et al. 2011; Ziska 2011). While $\mathrm{CO}_{2}$ is mainly expected to influence crop-weed competition, the most likely effect of a rising temperature is the northwards expansion of native and invasive weed species (Hatfield et al. 2011).

In comparison to many diseases and insect pests, weeds are relatively non-mobile, and their spread and establishment into new regions is expected to take longer than for other pest groups. However, as projected warming may exceed maximum rates of plant migration in postglacial periods (Malcolm et al. 2002), it could favor the most mobile weed species. Many agricultural weeds have characteristics associated with long-distance dissemination and a wide geographic range such as small seeds, phenotypic plasticity, and a short juvenile period that suggests that agricultural weeds may be among the fastest to spread (Dukes and Mooney 2000).

Most of the current information on the impact of climate changes on future weed distribution is based on predictions performed using bioclimatic envelope models (Hyvönen et al. 2012). However, these models have a limited value for predicting the long-term changes in the composition of weed communities (Thuiller et al. 2008). Firstly, climatic conditions alone cannot predict range shifts without considering biotic and management practices such as soil type, tillage practice, and cropping sequence. Secondly, the bioclimatic envelope models assume that weed species will only gain foothold in areas that have a climate similar to its native range. However, this assumption has recently been challenged by studies revealing that the range expansion of alien species exceeded that predicted by the models used (Clements and DiTommaso 2011). Rapid genetic evolution and/or phenotypic plasticity may explain these observations (Clements and DiTommaso 2011; Maron et al. 2004).

For an agricultural weed to be successful, it must adapt not only to a given climate but also to the constraints of the cropping system. Thus, the range shift of a weed species should not only be studied in the context of climate but should also include biotic parameters which have rarely been the case so far. The term "niche" is often used in the context of range shifts. According to Hutchinson (1957), the abiotic factors, and especially climate, determine the fundamental niche of a species while the interactions with the biotic factors together with the dispersal properties determine the realized niche of a species. Although the concepts of fundamental and realized niches are useful also for understanding range shifts of agricultural weeds, they do not take into account the 


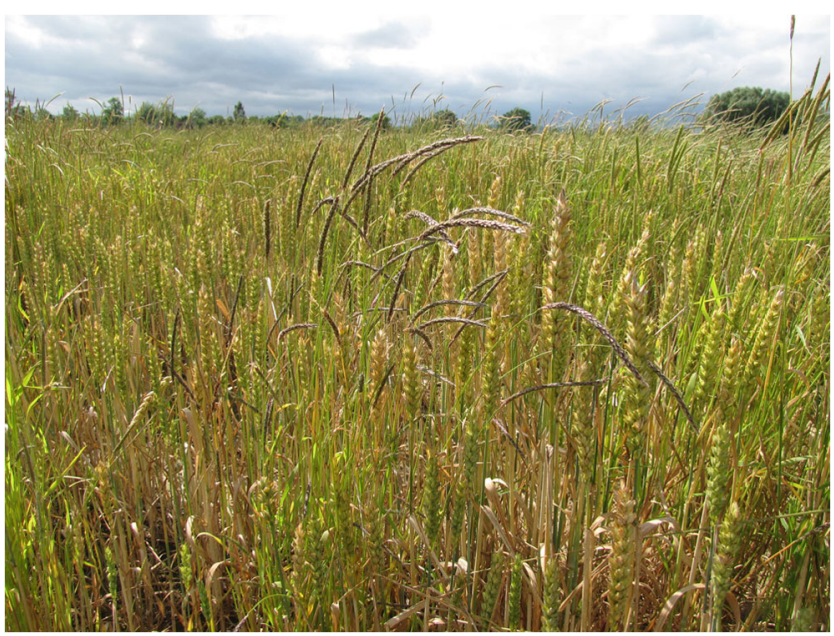

Fig. 4 Black grass (Alopecurus myosuroides) infestation in winter wheat crop. This weed is subjected to a possible northward shift in Europe

economic impact of agricultural weeds. To overcome this shortcoming, McDonald et al. (2009) introduced the concept of the "damage niche." The latter is defined as "the environmental conditions that make specific weed abundant, competitive, and therefore damaging the production of particular crops." Determining the damage niche of a weed species requires information on the crop-weed interactions and is thus region and cropping system specific.

Despite its relevance to the impact of climate change on the distribution and impact of agricultural weeds, the "damage niche" concept has only been applied in a few other studies (Stratonovitch et al. 2012; Bradley 2013). Using the damage niche-based concept in conjunction with the HadCM3 projections for the periods 2046-2065 and 2080-2099, Stratonovitch et al. (2012) found a possible northward shift in the range of black grass (Alopecurus myosuroides) in winter wheat (Fig. 4). Moreover, they also observed a local-scale difference due to variations in soil type and water holding capacity. The competitive balance was predicted to shift in favor of the crop due to its deeper root system making the crop less prone than the competing weed to the more frequent drought stress events predicted. In short, this means, in this context, the damage niche was predicted to reduce, rather than increase, under climate change.

\section{Diversification of current plant protection strategies to mitigate climate change effects}

Current agricultural practices may need to be revisited because of climate change. IPM is a widely used strategy that integrates cultural, biological, and chemical controls to reduce harmful insect populations below a threshold which otherwise will cause economic losses. Because many insects develop more rapidly in response to rising temperatures (Trumble and
Butler 2009), crop damage could occur more rapidly than expected. In addition, as temperatures increase, the frequency of spring frosts will decline and the resulting extended frostfree periods will increase the duration and intensity of insect outbreaks. Indeed, farmers may be tempted to take advantage of the changing climate by planting crops earlier in the season. However, plants will then be available for insect pests earlier in the annual cycle, allowing populations to get a quicker start and potentially add additional generations during a typical growing season (Trumble and Butler 2009). It could translate to increased insect and pathogen pressure at the end of the season, resulting in higher associated yield losses. In some cases, small differences in temperature and humidity can determine the preferred protection strategy. A study in the central valley of California (Daane and Caltagirone 1989) showed that an IPM strategy based on the use of parasitoids against the black scale Saissetia oleae could work in the northern part of the valley. In the southern part, however, the slightly warmer and drier conditions were not favorable to the parasitoids. For this reason, the authors recommended heavy pruning in the area to exacerbate the effect of hot and dry conditions on summer mortality of the pest.

Indirect effects of climate change may also occur due to shifts in cropping patterns and crop distributions. New combinations of crops may be grown in particular regions and in different growing conditions with changing husbandry practices. If ecological knowledge and farmer experience are lacking for these new situations, unexpected outbreaks may become more frequent or more difficult to manage. Taking into account the uncertainty of local and temporal climate change effects in different regions of the world on plant characteristics and crop production, pest and disease epidemiology, and infection probabilities (Chakraborty 2013), designing appropriate and reliable crop protection strategies will be a real challenge. Hence, the possible effects of climate change on pest evolution, as described earlier, raise several questions concerning the consequences for our current crop protection tools and approaches. In particular, can we rely in the future on chemical pesticides as we overwhelmingly do today? And if not, are our current IPM tools suitable to be used in the future? In order to address these questions, we (1) need to study new resistance genes with optimal expression under variable climate change situations; (2) have to collect more data on the behavior of pests, diseases, and weeds in future circumstances and the efficacy of biological control organisms; (3) have to assess the role for alternative plant hosts and intercropping and landscape management for pests, diseases, and weeds as well as for beneficial organisms; and (4) need to develop pest risk analysis models to predict the risk of new invasive pests, their chances of establishment in new cropping areas, and how to counteract disease disasters through local adaptive and resilient cropping and crop protection systems. In other words, all the questions we currently address in order to develop robust 
IPM less reliant on chemical crop protection can mutatis mutandis be raised to develop locally adaptive and diversified IPM systems which are resilient enough to meet extreme weather fluctuations as a result of climate change.

Crop protection per se has an important role to play in mitigating climate change. Crop protection practices can contribute to the reduction of GHG emissions. In the UK, arable production systems account for more than $7 \%$ of the total $\mathrm{GHG}$ emission (Carlton et al. 2012). The authors suggested that conventional crop production systems coupled to reduced tillage is generally the best for producing high yields to minimize GHG emissions and to contribute to global food security. Optimum control of pests is an insurance for optimum exploitation of all other investments in crop production including losses in invested nitrogen, a significant producer of GHG. A quantified example on the fungicide use against diseases of UK oilseed rape showed that yield benefits from fungicide use significantly outweigh GHG emissions associated with production and application of the fungicide. Reduced GHG emissions associated with more efficient use of nitrogen per ton of yield are considerable. For UK wheat, barley, and oilseed rape use, such benefits are $>1.5 \mathrm{Mt} \mathrm{CO}_{2}$ equivalent per year (Carlton et al. 2012). Likewise, in forest systems, crop protection practices might be the most important factor in enhancing sequestration of $\mathrm{CO}_{2}$ by the "green lungs" of the world. However, it is surprising that in most climate reports and climate change debates, the role of plant pests and diseases in mitigating the effects of climate change are, at best, only marginally covered. Hence, time has come to elaborate new crop protection strategies that are robust and reliable enough for the challenges of changing climatic conditions and more stringent human and environmental protection.

\section{Priorities and action points to improve current plant protection practices}

Faced with the uncertainty regarding the effects of changing climate on crop protection, and based on the issues discussed, a number of proposed action points, in terms of research needs and the enhanced national and international organization of research and extension effort to help face future challenges, have been identified and are presented here for consideration. While projected changes do not automatically translate into "doom and gloom" scenarios, the level of uncertainty is such that policy, research, and extension should be prepared for potential worstcase scenarios or extreme events following a "no regrets" approach. Preparation, in turn, should produce increased resilience vis-à-vis pests. This high level of uncertainty should be considered when taking into account models, which are perceived as essential tools to support decision making. This is true for models driven either by weather changes or those tackling exotic pest establishment. The predictive power of modeling on the effects of climate change on pest and disease occurrence is seriously hindered by biotic and abiotic uncertainties. This means that when using model outputs for policy or farm management, this uncertainty should be considered in order to develop flexible responses with the capacity to be continuously adapted and updated with new data and when it comes available. Hereinafter, we list some priorities and recommend actions plans which we feel are required to mitigate climate change effects in future crop protection, particularly in the EU, but also of global relevance.

\subsection{Human resources}

Historically, agricultural systems have been able to adapt to face major changes involving human resources. For example, 2 to 3 years after the initial arrival of T. absoluta in Europe, there has been a drastic reduction in severity of damage thanks, in large part, to farmers having previous exposure and control experience with other pests which have led to a solid generic understanding and appreciation toward the management and control of the impact of this pest. This was particularly true in areas of Spain that had experienced the earlier invasion and had subsequently developed IPM responses to it.

The increased uncertainty and accelerated rate and intensity of disturbances we are now witnessing mean that this capacity for change needs to be pro-actively accelerated. Paradoxically, appropriate expertise and financial support has been declining over the years in several sectors. This can be seen in the area of extension services. The USA's long-term reliance on herbicide-resistant crops, for example, has translated into a reduced number of advisers with weed management skills. Lack of the required expertise can also be seen in other areas of crop protection. Regarding the threat posed by new and significantly more virulent yellow rust strains, for example (although the same could be said of other crop-pathogen systems, e.g., potato), identifying new and more aggressive strains requires highly skilled staff and technical expertise that is generally becoming increasingly less available in European countries. For example, a recent report of the UK parliament highlighted a range of problems in the sector of plant protection (http://www.publications.parliament.uk/pa/cm201314/ cmselect/cmenvfru/469/46908.htm). Among them, reduced fund availability and lack of relevant expertise in the field of crop protection, both in terms of the numbers of people and their technical background, have been reported to severely affect prevention-based management. The British Society of Plant Pathology has recently carried out a survey (http://www. bspp.org.uk/society/docs/bspp-plant-pathology-audit-2012. pdf) which highlights problems with the current levels of plant pathology education and training in the UK. Action needs to be taken to reverse the decline in skilled crop protection specialists in Europe. 
Advisory services currently focus on optimizing existing systems, and, faced with climate change, this approach will have to change in order to concentrate on making systems more resilient. Diversifying cropping systems in general with strategies such as more varied rotations, as recommended for tackling Diabrotica in maize (Gray et al. 2009), can be regarded as major leverage points which can be addressed via extension services. Changes will also be required regarding the role of extension within the innovation process. The involvement of multiple stakeholders, including public-private partnerships, and new, more collective approaches to extension are required to meet the challenges of building more robust cropping systems.

One approach which could be usefully employed to address shortcomings in human and financial resources is to join forces across borders, pool resources, and develop new synergistic collaborations for pest management. Examples are EUROWHEAT (http://www.eurowheat.org/EuroWheat.asp) and EUROBLIGHT (http://euroblight.net/about-euroblight/) which are internet-based platforms on diseases of wheat and potato, respectively. These platforms bring together all the information available to date at European level on these pathosystems in order to ensure the ready use of the data. In particular, new disease outbreaks, resistance data are updated on a regular basis to support effective disease control, deployment of host resistances, and breeding programs.

Cooperation between the historically compartmentalized experts in plant health and crop protection could help to further draw on shared expertise regarding the anticipation of invasive and alien species and modeling. This is true in particular to understanding the processes leading to establishment of alien species. However, distinctions between invasive species and the emergence of more aggressive strains of existing, indigenous ones may not always be pertinent when considering their spread and impact. Large research groups such as Climapest, which brings together 134 researchers from Brazil and Argentina, and are already working on this issue, could be linked to other groups even though conditions in Europe will differ from those in South America.

Another useful avenue is to develop participatory approaches involving new stakeholders and farmers inspired by Web 2.0 and taking advantage of the new technologies which make information exchange easier. This type of approach could, for example, help improve worldwide tracking of global wheat rust (and in real-time). We can look to existing participatory systems as possible models for this approach. Examples are the Finnish web application "EnviObserver" and the French "Ecophyto épidémiosurveillance" regional networks. The first enables farmers to report pests with mobile phones while the second offers weekly bulletins. It should be noted, however, that farmers have a tendency to refrain from reporting the presence of regulated pests on their farm.

\subsection{Resilient cropping systems}

From the point of view of cropping systems, "preparing for the worst-case scenario" translates into uncovering what currently makes cropping systems resilient to extreme, variable, and unpredictable situations. Promising avenues to achieve resilience include genetic diversification and combinations of crop protection systems. An example developed for late blight in potato crops relies on varietal resistance coupled with new methods to monitor loss of resistance (http://euroblight.net/ potato-ipm/best-practice). Likewise, the combination of native arthropod natural enemies with entomopathogens against invasive species as those reported for T. absoluta in tomato crops could be effective (Molla et al. 2011). The literature review on this subject reveals a notable scarcity of knowledge and references. The lack of information is acute regarding what constitutes robust or resilient cropping systems and, more generally, how cropping systems can be managed to reduce the risks associated with invasive alien as well as rapidly evolving indigenous pest species under climate change. This reflects a serious knowledge gap within a priority research area and is one which needs urgent attention. Socio-economic researchers should work on these issues to ensure that the solutions proposed are appropriate for stakeholders.

\subsection{Crop-weed competition}

Although weeds have a much greater potential to cause crop losses than many insect pests and pathogens, the study of climate change impact on crop-weed competition has been largely overlooked. In some cases, differential responses between weeds and crops could be a source of opportunity. For example, red or weedy rice shows a much stronger response to rising $\mathrm{CO}_{2}$ than cultivated rice (Ziska et al. 2012) and consequently could serve as a unique source of genes which may potentially contribute to the adaptation of cultivated rice to climatic uncertainties. In addition, it is important to adopt the concept of the damage niche in future studies to take into account the impact of management practices and weeds on crop yields in a changing climate.

\subsection{Anticipation and international monitoring}

Strategies that identify the vulnerabilities of cropping systems prior to pest introduction and establishment are worthwhile preventative approaches. An example is the international collaboration between the UK and China (Fitt et al. 2008) to help the latter decrease the risk of invasion from Leptosphaeria maculans, the causal agent of Phoma canker of Brassica crops. The collaboration included support on pest risk analysis to determine the risk of entry and establishment of the pathogen, training on symptom recognition, PCR diagnostics, disease epidemiology, cultivar resistance screening techniques, 
surveys on the distribution of Phoma agents, and workshops with policy makers on risks and strategies to prevent the pathogen spread.

International and/or global coordination in the immediateand long-range surveillance and monitoring has also been identified as an invaluable tool to monitor both invasive alien species and the appearance of new and more aggressive strains of existing pest species. The Borlaug Global Rust Initiative (http://www.globalrust.org/traction/permalink/about37@1), covering 20 countries in several continents, is an example of coordination on new highly virulent strains of rust that have the potential to induce widespread wheat crop failures. It operates as a worldwide warning system for potential rust outbreaks. Within the EU, Europhyt (http://ec.europa.eu/food/plant/plant health_biosafety/europhyt/index_en.htm) acts as an effective rapid alert system for Member States with regard risk management responses to interceptions and incursions of harmful organisms of importance to all associated countries within the Union. The creation of a truly global database, or integrated information exchange platform, on harmful organisms accessible by all countries could be another useful step, for example, integrating the expertise and intelligence gathering and surveillance of regional plant protection organizations toward an overarching view.

\subsection{Breeding for and sustaining resistance}

A priority area should be breeding for resistance and devising strategies to sustain that resistance. It should follow an assessment of how existing farming systems and crop rotation practices and varieties will perform under changing climatic conditions. It requires breeding for varieties that are both adapted to changing climates and those containing temperature-stable resistance genes. Deployment strategies or the combination of new varieties with other methods will be needed to ensure that resistance to pest is sustained and durable.

\subsection{Biological control}

Research and development in biological control is another priority area which will help to adapt cropping systems to the appearance of new pests and changing climatic conditions. In particular, biological control studies in arable crops are lacking which need to be addressed to reduce the reliance on pesticides on these species and consequent development of pest resistance to pesticides. Making use of opportunistic native natural enemies against new exotic pests can also be seen as a promising avenue. For example, promoting biocontrol services by using generalist natural enemies ( $\mathrm{Lu}$ et al. 2012), i.e., natural enemies able to attack a wide range of prey including those potential exotic and invasive ones, may increase the robustness of cropping systems when compared to systems relying mainly on pesticides which shows generally very poor biocontrol services. Looking beyond Europe, in North Africa and West and Central Asia, for example, there is a need for biological control agents specifically adapted to warmer and drier conditions; pro-active studies maybe developed to identify key natural enemies as possible biocontrol agents for management of potential invasive pest species.

\subsection{Pest risk analysis}

Even though there are recognized limits to pest risk analysis in terms of its power to predict establishment, it remains an important early warning tool. Pest risk analysis can help to identify those pest species which present the highest risk for European cropping systems. With pest risk analysis, it becomes possible to propose adaptations to cropping systems in advance or to conduct research on the ecological requirements and/or control options related to pest origins. Greater progress could be achieved with pest risk analysis if it could be made more spatially explicit or based on "hotspots" or case studies so that site-specific conditions affecting the likelihood of establishment are taken into account. Furthermore, enhanced international information exchange with regards to completely new and exotic disease threats and pressures, as highlighted in Section 5.7, are foreseen as a critical element of an effective, and often urgently required pest risk analysis, e.g., under an emergency incursion situation.

\section{Conclusion}

Climate-driven changes present challenges and opportunities for sustainable agriculture programs based on IPM. As suggested by Anderson et al. (2004), research on the effect of climate change on pest evolution must shift from passive cataloging to analysis and interpretation of the factors favoring outbreaks. If Europe's agricultural production is to keep pace with a growing food demand while satisfying environmental goals, we will need new cultivars, major changes in IPM programs, increased funding, and improved response time to new and evolving pests that lead to outbreaks.

Although climate change is expected to impact European agriculture, by influencing the stability of crop yield, information on the real consequences are lacking, and studies in this regard remain in their infancy. Our inability to make confident predictions highlights a need for new research on several fronts. Policies are needed to fill this uncertainty gap by considering a wide range of possible scenarios. Hence, research based on a broader collaborative approach should be made in order to develop anticipatory adaptive strategies resulting in more resilient cropping strategies and stabilized 
yields. Toward this ultimate aim, enhanced interregional, transnational, and global networking of researchers and stakeholders, at all levels across the plant health/crop protection spectrum, considering the scale and increasing pressures on crop production and yields, is an effective way to better use the limited resources in order to address this twenty-first century challenge in an ever increasing integrated global context.

Acknowledgments This report is the fruit of a joint initiative of the Institute for Prospective Technological Studies, one of the institutes in the European Commission's Joint Research Centre, and the ENDURE European Research Group, which brings together some of Europe's leading agricultural research, teaching, and extension institutes with a special interest in IPM. This study is built on technical reports and a workshop of international experts. The authors would like to thank all those who contributed to what we believe is a valuable and much-needed insight into the research and policy implications of meeting this twenty-first century challenge. The authors also thank Andrew Lewer for his collaboration on the earlier draft of the manuscript.

\section{References}

Ainsworth EA, Long SP (2005) What have we learned from 15 years of free-air $\mathrm{CO} 2$ enrichment (FACE)? A meta-analytic review of the responses of photosynthesis, canopy properties and plant production to rising CO2. New Phytol 165:351-372. doi:10.1111/j.1469-8137. 2004.01224.x

Aluja M, Guillén L, Rull J et al (2011) Is the alpine divide becoming more permeable to biological invasions? Insights on the invasion and establishment of the Walnut Husk Fly, Rhagoletis completa (Diptera: Tephritidae) in Switzerland. Bull Entomol Res 101:451465. doi:10.1017/S0007485311000010

Anderson P, Cunningham AA, Patel NG et al (2004) Emerging infectious diseases of plants: pathogen pollution, climate change and agrotechnology drivers. Trend Ecol Evol 19:533-544. doi:10. 1016/j.tree.2004.07.021

Assad ED, Pinto HS, Zullo Junior J, Avila AMH (2004) Impacto das mudancas climaticas no zoneamento agroclimatico do cafeno Brasil. Pesqui Agrop Brasil 39:1057-1064

Baltrus DA (2013) Exploring the costs of horizontal gene transfer. Trend Ecol Evol 28:489-495. doi:10.1016/j.tree.2013.04.002

Barbetti MJ, Banga SS, Salisbury PA (2012) Challenges for crop production and management from pathogen biodiversity and diseases under current and future climate scenarios - case study with oilseed Brassicas. Field Crop Res 127:225-240. doi:10.1016/j.fcr.2011.11. 021

Barnes AP, Wreford A, Butterworth MH et al (2010) Adaptation to increasing severity of phoma stem canker on winter oilseed rape in the UK under climate change. J Agric Sci 148:683-694. doi:10. 1017/S002185961000064X

Bartoli C, Lamichhane JR, Berge O, Guilbaud C, Varvaro L, Balestra GM, Vinatzer BA, Morris CE (2014) A framework to gage the epidemic potential of plant pathogens in environmental reservoirs: the example of kiwifruit canker. Mol Plant Pathol. doi:10.1111/mpp. 12167

Battisti A, Stastny M, Netherer S et al (2005) Expansion of geographic range in the pine processionary moth caused by increased winter temperatures. Ecol Appl 15:2084-2096. doi: 10.1890/04-1903
Beed F, Benedetti A, Cardinali G, et al. (2011) Climate change and microorganism genetic resources for food and agriculture: State of knowledge, risks and opportunities. Commission on genetic resources for food and agriculture, FAO. doi: http://www.fao.org/docrep/meeting/ 022/mb392e.pdf

Bergot M, Cloppet E, Perarnaud V et al (2004) Simulation of potential range expansion of oak disease caused by Phytophthora cinnamomi under climate change. Glob Chang Biol 10:1539-1552. doi:10. 1111/j.1365-2486.2004.00824.x

Bradley BA (2013) Distribution models of invasive plants over-estimate potential impact. Biol Invasions 15:1417-1429. doi:10.1007/ s10530-012-0380-0

Bradshaw WE, Holzapfel CM (2011) Genetic shift in photoperiodic response correlated with global warming. Proc Natl Acad Sci U S A 98:14509-14511. doi:10.1073/pnas. 241391498

Brasier CM, Jones B, Webber JF (2010) New tree hosts and new disease etiologies beneath larch (Larix) infected by Phytophthora ramorum in the UK. Abstracts: 5th IUFRO Phytophthoras in Forests and Natural Ecosystems. Auckland and Rotorua, New Zealand, p 25

Burdon JJ, Thrall PH, Ericson L (2006) The current and future dynamics of disease inplant communities. Annu Rev Phytopathol 44:19-39. doi:10.1146/annurev.phyto.43.040204.140238

Bustamante M, Robledo-Abad C, Harper R et al (2014) Co-benefits, trade offs, barriers and policies for greenhouse gas mitigation in the agriculture, forestry and other land use sector. Glob Chang Biol. doi:10.1111/gcb.12591

Butterworth MH, Semenov M, Barnes AP et al (2010) North-south divide; contrasting impacts of climate change on crop yields in Scotland and England. J R Soc Interface 7:123-130. doi:10.1098/ rsif.2009.0111

Carlton RR, West JS, Smith P, Fitt BDL (2012) A comparison of GHG emissions from UK field crop production under selected arable systems with reference to disease control. Eur J Plant Pathol 133: 333-351. doi:10.1007/s10658-012-9961-0

Chakraborty S (2013) Migrate or evolve: options for plant pathogens underclimate change. Glob Chang Biol 19:1985-2000. doi:10.1111/ gcb. 12205

Chakraborty S, Dutta S (2003) How will plant pathogens adapt to host plant resistance at elevated $\mathrm{CO} 2$ under a changing climate. New Phytol 159:733-742. doi:10.1046/j.1469-8137.2003.00842.x

Chakraborty S, Newton AC (2011) Climate change, plant diseases and food security: an overview. Plant Pathol 60:2-14. doi:10.1111/j. 1365-3059.2010.02411.x

Clements DR, DiTommaso A (2011) Climate change and weed adaptation: can evolution of invasive plants lead to greater range expansion than forecasted? Weed Res 51:227-240. doi:10.1111/j.1365-3180. 2011.00850.x

Czajkowski R, Pérombelon MCM, van Veen JA, van der Wolf JM (2011) Control of blackleg and tuber soft rot of potato caused by Pectobacterium and Dickeya species: a review. Plant Pathol 60: 999-1013. doi:10.1111/j.1365-3059.2011.02470.x

Daane KM, Caltagirone LE (1989) Biological control of black scale in olives. Calif Agric 43:9-11

Desneux N, Wajnberg E, Wyckhuys KAG et al (2010) Biological invasion of European tomato crops by Tuta absoluta: ecology, geographic expansion and prospects for biological control. J Pest Sci 83:197215. doi:10.1007/s10340-010-0321-6

Desneux N, Luna MG, Guillemaud T, Urbaneja A (2011) The invasive South American tomato pinworm, Tuta absoluta, continues to spread in Afro-Eurasia and beyond - the new threat to tomato world production. J Pest Sci 84:403-408. doi:10.1007/s10340-011-0398-6

Dukes JS, Mooney HA (2000) Does global change increase the success of biological invaders? Trend Ecol Evol 14:135-139. doi:10.1016/ S0169-5347(98)01554-7 
Durgapal JC, Singh B (1980) Taxomony of pseudomonads pathogenic to horse-chestnut, wild fig and wild cherry in India. Indian Phytopathol 33:533-535

Eastburn DA, McElrone AJ, Bilginc DD (2011) Influence of atmospheric and climatic change on plant-pathogen interactions. Plant Pathol 60: 54-69. doi:10.1111/j.1365-3059.2010.02402.x

European Commission (2009a) White Paper from the European commission to the Council, the European Parliament, the European Economic and Social Committee and the Committee of the Regions - Adapting to climate change: Towards a European framework for action (COM(2009) 147/4) (01.04.20)

European Commission (2009b) Regulation (EC) No 1107/2009 of the European Parliamnt and of the Council of 21 October 2009 concerning the placing of plant protection products on the market and repealing Council Directives 79/117/EEC and 91/414/EEC

European Commission (2009c) Directive 2009/128/EC of the European Parliamnt and of the Council of 21 October 2009 establishing a framework for Community action to achieve the sustainable use of pesticides

Evans N, Baierl A, Semenov MA et al (2008) Range and severity of a plant disease increased by global warming. J R Soc Interface 5:525531. doi:10.1098/rsif.2007.1136

Fenton B, Woodford JAT, Malloch G (1998) Analysis of clonal diversity of the peach-potato aphid, Myzus persicae (Sulzer), in Scotland, UK and evidence for the existence of a predominant clone. Mol Ecol 7: 1475-1487. doi:10.1046/j.1365-294x

Fernandes FR, de Albuquerque LC, Giordano LDB et al (2008) Diversity and prevalence of Brazilian bipartite bergomovirus species associated to tomoatoes. Virus Gene 36:251-258. doi:10.1007/s11262007-0184-y

Fitt BDL, Hu BC, Li ZQ et al (2008) Strategies to prevent spread of Leptosphaeria maculans (phoma stem canker) onto oilseed rape crops in China: costs and benefits. Plant Pathol 57:652-664. doi: 10.1111/j.1365-3059.2008.01841.x

Fletcher J, Luster D, Bostock R et al (2010) Emerging infectious diseases. In: Scheld WM (ed) Emerging Infections. ASM Press, Washington DC, pp 337-366

Foley JA, Ramankutty N, Brauman KA et al (2011) Solutions for a cultivated planet. Nature 478:337-342. doi:10.1038/nature10452

Garrett KA, Forbes GA, Savary S et al (2011) Complexity in climatechange impacts: an analytical framework for effects mediated by plant disease. Plant Pathol 60:15-30. doi:10.1111/j.1365-3059. 2010.02409.x

Ghini R, Bettiol W, Hamada E (2011) Diseases in tropical and plantation crops as affected by climate changes: current knowledge and perspectives. Plant Pathol 60:122-132. doi:10.1111/j.1365-3059.2010. 02403.x

Gray ME, Sappington TW, Miller NJ et al (2009) Adaptation and invasiveness of western corn rootworm: intensifying research on a worsening pest. Annu Rev Entomol 54:303-321. doi:10.1146/ annurev.ento.54.110807.090434

$\mathrm{Gu} \mathrm{G}, \mathrm{Hu}$ J, Cevallos-Cevallos JM et al (2011) Internal colonization of Salmonella enterica serovar Typhimurium in tomato plants. PLoS One 6:e27340

Gu G, Cevallos-Cevallos JM, Vallad GE et al (2013) Organically managed soils reduce internal colonization of tomato plants by Salmonella enterica serovar Typhimurium. Phytopathology 103:381-388

Guo H, Sun Y, Li Y et al (2013) Pea aphid promotes amino acid metabolism both in Medicago truncatula and bacteriocytes to favor aphid population growth under elevated CO2. Glob Chang Biol 19: 3210-3223. doi:10.1111/gcb.12260

Gutierrez AP, Ponti L, Cossu QA (2009) Effects of climate warming on olive and olive ßy (Bactrocera oleae (Gmelin)) in California and Italy. Clim Chang 95:195-217. doi:10.1007/s10584-008-9528-4

Hadley Centre (2007) Climate Change. www.metoffice.gov.uk/ climatechange. Exeter, Devon, UK
Hatfield JL, Boote KJ, Kimball BA et al (2011) Climate impacts on agriculture: implications for crop production. Agron J 103:351370. doi:10.2134/agronj2010.0303

Hirneisen KA, Kniel KE (2013) Norovirus surrogate survival on spinach during preharvest growth. Phytopathology 103:389-394

Holden N, Pritchard L, Toth I (2009) Plants as an alternative environmental reservoir for human pathogenic enterobacteria. FEMS Microbiol Rev 33:689-703

Hossard L, Philibert A, Bertrand M et al (2014) Effects of halving pesticide use on wheat production. Sci Rep. doi:10.1038/srep04405

Hovmøller MS, Yahyaoui AH, Milus EA, Justesen AF (2008) Rapid global spread of two aggressive strains of a wheat rust fungus. Mol Ecol 17:3818-3826. doi:10.1111/j.1365-294X.2008.03886.x

Hovmøller MS, Walter S, Justesen AF (2010) Escalating threat of wheat rusts. Science 329:369. doi:10.1126/science.1194925

Hovmøller MS, Sørensen CK, Walter S, Justesen AF (2011) Diversity of Puccinia striiformis on cereals and grasses. Annu Rev Phytopathol 49:197-217. doi:10.1146/annurev-phyto-072910-095230

Huang Y-J, Pirie EJ, Evans N et al (2009) Quantitative resistance to symptomless growth of Leptosphaeria maculans (phoma stem canker) in Brassica napus (oilseed rape). Plant Pathol 58:314-323. doi: 10.1111/j.1365-3059.2008.01957.x

Huber L, Gillespie TJ (1992) Modeling leaf wetness in relation to plantdisease epidemiology. Annu Rev Phytopathol 30:553-577. doi:10. 1146/annurev.py.30.090192.003005

Hutchinson GE (1957) Concluding remarks. Cold Spring Harb Symp Quantum Biol 22:415-427. doi:10.1101/SQB.1957.022.01.039

Hyvönen T, Luoto M, Uotila P (2012) Assessment of weed establishment risk in a changing European climate. Agric Food Sci 21:348-360

IPCC (2007) Climate Change 2007: Synthesis Report. Contribution of Working Groups I, IIand III to the Fourth Assessment Report of the Intergovernmental Panel on ClimateChange (eds Core Writing Team, Pachauri RK, Reisinger A). IPCC, Geneva, Switzerland

IPCC (2014) Climate Change. http://www.ipcc.ch/pdf/assessment-report/ ar5/syr/SYR_AR5_LONGERREPORT.pdf

Isebaert S, De Saeger S, Devreese R, Verhoeven R, Maene P, Heremans B, Haesaert G (2009) Mycotoxin-producing Fusarium species occurring in winter wheat in Belgium (Flanders) during 2002-2005. J Phytopathol 157:108-116. doi:10.1111/j.1439-0434.2008.01443.x

Jones R, Barbetti M (2012) Influence of climate change on plant disease infections andepidemics caused by viruses and bacteria. $\mathrm{CAB}$ reviews: perspectives in Agriculture, Veterinary Science. Nutr Nat Resour 7:1-31

Jung T (2009) Beech decline in central Europe driven by the interaction between Phytophthora infections and climatic extremes. For Pathol 39:73-94. doi:10.1111/j.1439-0329.2008.00566.x

Juroszek P, von Tiedemann A (2011) Potential strategies and future requirements for plant disease management under a changing climate. Plant Pathol 60:100-112. doi:10.1111/j.1365-3059.2010. 02410.x

Klerks MM, Franz E, van Gent-Pelzer M et al (2007) Differential interaction of Salmonella enterica serovars with lettuce cultivars and plant-microbe factors influencing the colonization efficiency. ISME J 1:620-631

Lamichhane JR (2014) Xanthomonas arboricola diseases of stone fruit, ammond and walnut trees: progress toward understanding and management. Plant Dis 98:1600-1610. doi:10.1094/PDIS-08-14-0831-FE

Lamichhane JR, Varvaro L, Parisi L et al (2014) Disease and frost damage of woody plants caused by Pseudomonas syringe: seeing the forest for the trees. Adv Agron 126:235-295. doi:10.1016/B978-0-12800132-5.00004-3

Licciardi S, Assogba-Komlan F, Sidick I et al (2008) A temporary tunnel screen as an eco-friendly method for small-scale growers to protect cabbage crop in Benin. Int J Trop Insect Sci 27:152-158. doi:10. 1017/S1742758407883184 
Lipsitch M, Singer RS, Levin BR (2002) Antibiotics in agriculture: when is it time to close the barn door. Proc Natl Acad Sci U S A 99:S572-S574

Liu D, Trumble JT (2007) Comparative fitness of invasive and native populations of the potato psyllid (Bactericera cockerelli). Entomol Exp Appl 123:35-42. doi:10.1111/j.1570-7458.2007.00521.x

Logan JA, Powell JA (2001) Ghost forests, global warming and the mountain pine beetle. Am Entomol 47:160-173

Lu YH, Wu KM, Jiang YY et al (2012) Widespread adoption of Bt cotton and insecticide decrease promotes biocontrol services. Nature 487: 362-365

Luck J, Spackman M, Freeman A et al (2011) Climate change and diseases of food crops. Plant Pathol 60:113-121. doi:10.1111/j. 1365-3059.2010.02414.x

Luo Q, Bellotti W, Williams M, Wang E (2009) Adaptation to climate change of wheat growing in South Australia: analysis of management and breeding strategies. Agric Ecosyst Environ 129:261-267. doi:10.1016/j.agee.2008.09.010

Madgwick JW, West JS, White RP et al (2011) Impacts of climate change on wheat anthesis and Fusarium ear blight in the UK. J Plant Pathol 129:117-131. doi:10.1007/s10658-010-9739-1

Malcolm JR, Markham A, Neilson RP, Garaci M (2002) Estimated migration rates under scenarios of global climate change. $\mathrm{J}$ Biogeogr 29:835-849. doi:10.1046/j.1365-2699.2002.00702.x

Maron JL, Vilà M, Bommarco R et al (2004) Rapid evolution of an invasive plant. Ecol Monogr 74:261-280. doi:10.1890/03-4027

McDonald A, Riha S, Ditommaso A, Degaetano A (2009) Climate change and the geography of weed damage: analysis of US maize systems suggests the potential for significant range transformations. Agric Ecosyst Environ 130:131-140. doi:10.1016/j.agee.2008.12.007

Mesaros N, Nordmann P, Plésiat P et al (2007) Pseudomonas aeruginosa: resistance and therapeutic options at the turn of the new millennium. Clin Microbiol Infect 13:560-578

Milus EA, Kristensen K, Hovmøller MS (2009) Evidence for increased aggressiveness in a recent widespread strain of Puccinia striiformis f. sp. tritici causing stripe rust of wheat. Phytopathology 99:89-94. doi:10.1094/PHYTO-99-1-0089

Molla O, Gonzalez-Cabrera J, Urbaneja A (2011) The combined use of Bacillus thuringiensis and Nesidiocoris tenuis against the tomato borer Tuta absoluta. Biocontrol 56:883-891. doi:10.1007/s10526011-9353-y

Mondal KK, Mani C, Singh J et al (2012) Fruit rot of Tinda caused by Pseudomonas aeruginosa - a new report from India. Plant Dis 96:141

Noel JT, Arrach N, Alagely A et al (2010) Specific responses of Salmonella enterica to tomato varieties and fruit ripeness identified by in vivo expression technology. PLoS One 5:e12406

Oerke EC (2006) Crop losses to pests. J Agric Sci 144:31-43. doi:10. $1017 / \mathrm{S} 0021859605005708$

Pachauri RK, Reisinger A (2007) Climate Change 2007: Synthesis Report. Contribution ofWorking Groups I, II and III to the Fourth Assessment Report of the Intergovernmental Panel on Climate Change. Geneva, Switzerland: IPCC

Pangga I, Hanan J, Chakraborty S (2013) Climate change impacts on plant canopyarchitecture: implications for pest and pathogen management. Eur J Plant Pathol 135:595-610. doi:10.1007/s10658-012-0118-y

Parmesan C (2006) Ecological and evolutionary responses to recent climate change. Ann Rev Ecol Evol Syst 37:637-669. doi:10. 1146/annurev.ecolsys.37.091305.110100

Paterson RRM, Lima N (2010) How will climate change affect mycotoxins in food? Food Res Int 43:1902-1914. doi:10.1016/j.foodres. 2009.07.010

Radcliffe EB, Ragsdale DW (2002) Aphid-transmitted potato viruses: the importance of understanding vector biology. Am J Pot Res 79:353386. doi:10.1007/BF02870173

Roy HE, Peyton J, Aldridge DC et al (2014) Horizon scanning for invasive alien species with the potential to threaten biodiversity in Great Britain. Glob Chang Biol. doi:10.1111/gcb.12603
Samietz S, Stoeckli S, Hirschi M, et al. (2014) Modelling the impact of climate change on sustainable management of the codling moth (Cydia pomonella L.) as key pest in apple. Acta Hort. in press

Sarfraz M, Keddie AB, Dosdall LM (2005) Biological control of the diamondback moth, Plutella xylostella: a review. Biocontrol Sci Technol 15:763-789. doi:10.1080/09583150500136956

Scherm H (2004) Climate change: can we predict the impacts on plant pathology and pest management? Can J Plant Pathol 26:267-273. doi:10.1080/07060660409507143

Shaw MW, Osborne TM (2011) Geographic distribution of plant pathogens in response to climate change. Plant Pathol 60:31-43. doi:10. 1111/j.1365-3059.2010.02407.x

Stephens AEA, Kriticos DJ, Leriche A (2007) The current and future potential geographical distribution of the oriental fruit fly, Bactrocera dorsalis (Diptera: Tephritidae). Bull Entomol Res 97: 369-378. doi:10.1007/978-3-642-27281-3 30

Stoeckli S, Hirschi M, Spirig C et al (2012) Impact of climate change on Voltinism and prospective Diapause induction of a global pest insect_Cydia pomonella (L.). PLoS One 7:e35723. doi:10.1371/ journal.pone. 0035723

Strange RN, Scott PR (2005) Plant disease: a threat to global food security. Annu Rev Phytopathol 43:83-116

Stratonovitch P, Storkey J, Semenov MA (2012) A process-based approach to modelling impacts of climate change on the damage niche of an agricultural weed. Global Chang Biol 18:2071-2080. doi:10. $1111 / j .1365-2486.2012 .02650 . x$

Sturrock RN, Frankel SJ, Brown AV, Al E (2011) Climate change and forest diseases. Plant Pathol 160:133-149. doi:10.1111/j.1365-3059. 2010.02406.x

Tahiri A, Sekkat A, Bennani A et al (2006) Distribution of tomato-infecting begomoviruses and Bemisia tabaci biotypes in Morocco. Ann Appl Biol 149:175-186. doi:10.1111/j.1744-7348.2006.00083.x

Thuiller W, Albert C, Araújo MB et al (2008) Predicting global change impacts on plant species' distributions: future challenges. Perspect Plant Ecol Evol Syst 9:137-152. doi:10.1016/j.ppees.2007.09.004

Trumble JT, Butler CD (2009) Climate change will exacerbate California's insect pest problems. Calif Agric 63:73-78

van Overbeek LS, Van Doorn J, Wichers JH et al (2014) The arable ecosystem as battleground for emergence of new human pathogens. Front Microbiol 5:1-17. doi:10.3389/fmicb.2014.00104

Vayssieres JF, Sinzogan A, Korie S et al (2009) Effectiveness of spinosad bait sprays (GF-120) in controlling mango-infesting fruit flies (Diptera: Tephritidae) in Benin. J Econ Entomol 102:515-521. doi:10.1603/029.102.0208

Venette RC (2009) Implication of global climate change on the distribution and activity of Phytophthora ramorum. In: McManus KA, Gottschalk KW (eds) Proceedings of the 20th U.S. Department of Agriculture Interagency Research Forum on Invasive Species. Department of Agriculture, Forest Service, Northern Research Station: General Technical Report NRS-P-51, Newtown Square, PA, USA, pp 58-59

Venette RC, Cohen SD (2006) Potential climatic suitability for establishment of Phytophthora ramorum within the contiguous United States. For Ecol Manag 231:18-26. doi:10.1016/j.foreco.2006.04. 036

Vilà M, Espinar JL, Hejda M et al (2011) Ecological impacts of invasive alien plants: ameta-analysis of their effects on species, communities and ecosystems. Ecol Lett 14:702-708. doi:10.1111/j.1461-0248. 2011.01628.x

Walther GR, Post E, Convey P et al (2002) Ecological responses to recent climate change. Nature 416:389-395. doi:10.1038/416389a

Ward TJ, Clear RM, Rooney AP et al (2008) An adaptive evolutionary shift in Fusarium head blight pathogen populations is driving the rapid spread of more toxigenic Fusarium graminearum in North America. Fungal Genet Biol 45:473-484. doi:10.1016/j.fgb.2007. 10.003 
Watson RT (2001) Climate Change 2001: Synthesis Report. A Contribution of Working Groups I, II, and III to the Third Assessment Report of the Intergovernmental Panel on Climate Change. Cambridge, UK: Cambridge

Webb KM, Ona I, Bai J, Garrett KA, Mew T, Cruz CMV, Leach JE (2011) A benefit of high temperature: increased effectiveness of a rice bacterial blight disease resistancegene. New Phytol 185:568-576. doi:10.1111/j.1469-8137.2009.03076.x

Webber JF (2008) Status of Phytophthora ramorum and P. kernoviae in Europe. In: Frankel SJ, Kliejunas JT, Palmieri KM (eds) Proceedings of the Sudden Oak Death Third Science Symposium. US Department of Agriculture, Forest Service, Pacific Southwest Research Station: General Technical Report PSW-GTR-214, Albany, CA, USA, pp 19-26

Webber JF, Mullet M, Brasier CM (2010) Dieback and mortality of plantation Japanese larch (Larix kaempferi) associated with infection by Phytophthora ramorum. New Dis Rep 22:19. doi:10.5197/j. 2044-0588.2010.022.019

Wellings CR (2011) Global status of stripe rust: a review of historical and current threats. Euphytica 179:1-13. doi:10.1007/s10681-0110360-y

West JS, Townsend JA, Stevens M, Fitt BDL (2012) Comparative biology of different palnt pathogens to estimate effects of climate change of crop diseases in Europe. Eur J Plant Pathol 133:315-331. doi:10. 1007/s10658-011-9932-x

Willmer P, Stone G, Johnston I (2000) Environmental Physiology of Animals. 768

Woodford JAT (1998) The impact of cropping policy on methods to control potato leafroll virus. Asp Appl Biol 17:163-171
Wright KM, Chapman S, McGeachy K et al (2013) The endophytic lifestyle of Escherichia coli O157:H7: quantification and internal localization in roots. Phytopathology 103:333-340

Yu L, Qin XY, Du J et al (2008) Bacterial leaf spot of tobacco caused by Pseudomonas aeruginosa in China. New Dis Rep 17:3

Zappalà L, Biondi A, Alma A et al (2013) Natural enemies of the South American moth, Tuta absoluta, in Europe, North Africa and Middle-East, and their potential use in pest control strategies. J Pest Sci 86:635-647. doi:10.1007/s10340013-0531-9

Zhou XL, Harrington R, Woiwod IP et al (1995) Effects of temperature on aphid phenology. Global Chang Biol 1:303-313. doi:10.1111/j. 1365-2486.1995.tb00029.x

Ziska LH (2010) Elevated carbon dioxide alters chemical management of Canada thistle in no-till soybean. Field Crop Res 199:299-303. doi: 10.1016/j.fcr.2010.07.018

Ziska LH (2011) Global climate change and carbon dioxide: assessing weed biology and management. In: Hillel D (ed) Handbook on climate change and agroecosystems: impacts, adaptation, and mitigation. Imperial College Press, London, pp 191-208

Ziska LH, Gealy DR, Tomecek MB et al (2012) Recent and projected increases in atmospheric $\mathrm{CO} 2$ concentration can enhance gene flow between wild and genetically altered rice (Oryza sativa). PLoS One 7:e37522. doi:10.1371/journal.pone.0037522

Ziter C, Robinson EA, Newman JA (2012) Climate change and voltinism in Californian insect pest species: sensitivity to location, scenario and climate model choice. Global Chang Biol 18:2771-2780. doi: 10.1111/j.1365-2486.2012.02748.x 